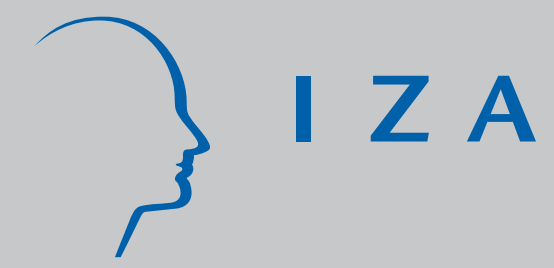

IZA DP No. 386

Threshold Values in German Labor Law and J ob Dynamics in Small Firms: The Case of the Disability Law

J oachim Wagner

Claus Schnabel

Arnd Kölling

November 2001 


\title{
Threshold Values in German Labor Law and Job Dynamics in Small Firms: The Case of the Disability Law
}

\author{
Joachim Wagner \\ Institute of Economics, University of Lüneburg, HWWA, Hamburg and IZA, Bonn \\ Claus Schnabel \\ Institute of Economics, Friedrich-Alexander-University Erlangen-Nuremberg \\ Arnd Kölling \\ Institute for Employment Research of the Federal Labor Services, Nuremberg
}

Discussion Paper No. 386

November 2001

\author{
IZA \\ P.O. Box 7240 \\ D-53072 Bonn \\ Germany \\ Tel.: +49-228-3894-0 \\ Fax: +49-228-3894-210 \\ Email: iza@iza.org
}

This Discussion Paper is issued within the framework of IZA's research area The Welfare State and Labor Markets. Any opinions expressed here are those of the author(s) and not those of the institute. Research disseminated by IZA may include views on policy, but the institute itself takes no institutional policy positions.

The Institute for the Study of Labor (IZA) in Bonn is a local and virtual international research center and a place of communication between science, politics and business. IZA is an independent, nonprofit limited liability company (Gesellschaft mit beschränkter Haftung) supported by the Deutsche Post AG. The center is associated with the University of Bonn and offers a stimulating research environment through its research networks, research support, and visitors and doctoral programs. IZA engages in (i) original and internationally competitive research in all fields of labor economics, (ii) development of policy concepts, and (iii) dissemination of research results and concepts to the interested public. The current research program deals with (1) mobility and flexibility of labor markets, (2) internationalization of labor markets and European integration, (3) the welfare state and labor markets, (4) labor markets in transition, (5) the future of work, (6) project evaluation and (7) general labor economics.

IZA Discussion Papers often represent preliminary work and are circulated to encourage discussion. Citation of such a paper should account for its provisional character. 
IZA Discussion Paper No. 386

November 2001

\section{ABSTRACT}

\section{Threshold Values in German Labor Law and Job Dynamics in Small Firms: The Case of the Disability Law*}

According to the German disability law, or Schwerbehindertengesetz, either six percent of all jobs in an establishment must be occupied by disabled empoyees or the firm has to pay a penalty of DM 200 per month for every job under consideration. This note reports results from the first econometric investigation of the impact of this rule on job dynamics in small firms. Based on data from the IAB Establishment Panel we find no clear-cut evidence that employment in establishments at the first threshold of the law reacts differently on demand shocks than establishments below or above the threshold.

JEL Classification: J23, J38

Keywords: Threshold values, disability law, labor demand

Joachim Wagner

Institute of Economics

University of Lüneburg

21332 Lüneburg

Germany

Tel.: +49 4131-78-2330

Fax: +49 4131-78-2026

Email:wagner@uni-lueneburg.de

* This paper uses data from the IAB Establishment Panel, financially supported by the ESF. A previous version has been presented at the Econometric Society European Meeting ESEM 2001, the European Association of Labour Economists EALE Conference 2001, and the Jahrestagung 2001 of the Verein fuer Socialpolitik. We thank our discussants and participants at these conferences and other workshops for helpful comments. We appreciate the suggestions of an anonymous referee. The usual disclaimer applies. 


\section{Introduction}

Like in many other countries, relations between employers and employees in Germany are governed by a huge number of laws. Often these rules do apply only in establishments above a critical size, and often these thresholds are defined by the number of employees (see Institut der deutschen Wirtschaft 1998). A case in point is the German disability law, or Schwerbehindertengesetz: For establishments with 16 or more employees it demands that either six percent of all jobs must be occupied by disabled empoyees or the firm has to pay a penalty of DM 200 per month for every job that should have been occupied by a disabled worker but that is not. ${ }^{1}$

For establishments with 15 employees (none of which is disabled) this law leads to a threshold value that is costly to cross: hiring one more (not disabled) employee increases costs by the wage and non-wage costs of this employee plus the penalty of DM 200 per month. If for example total labor costs per month for the job under consideration are DM 4000, this means an increase in the costs for hiring one more worker in an establishment at the threshold by 5 percent per month compared to firms below or above the threshold. These extra costs are often considered by businessmen (as well as by some economists) to form a barrier to job creation in small firms at the first threshold of the disability law. ${ }^{2}$ It is argued that firms with 15 employees facing a positive demand shock will be retentive of hiring one more (not disabled) employee, and will either in the short run extend the number of hours worked per employee (which is costly, too, due to the premia that have to be paid) or substitute capital for labor in the long run. ${ }^{3}$

Whether an establishment with 15 employees will cross the threshold under consideration depends on the size of the positive demand shock, among others. The larger the shock, the less

\footnotetext{
${ }^{1}$ This ruleapplied before October 2000. In the new law the quota is lowered to five percent, and the penalty depends on the degree to which this quota is met in a complicated non-linear way (see Deutscher Bundestag 2000).

2 See the survey by Friedrich and Hägele 1997. For a discussion of the law and the situation of disabled workers in Germany see Frick and Frick (1994), Henninges, Jung-Hammon and Gruber (1998), and Sadowski and Frick (1992).

${ }^{3}$ Note that hiring temporary workers is an option that can be used in the very short run only, because in the disability law employees with a contract length of more than eight weeks are not excluded from calculating the total number of workers. Due to missing information in the data used in our empirical study, however, we can not investigate the role of temporary employment.
} 
weight will be put on the DM 200 penalty per month. However, given that we have no reason to assume that the size distribution of shocks differs systematically between establishments below, at, or above the threshold, we hypothesize that establishments with 15 employees have a lower probability to create a new job than establishments with slightly less or more employees.

A similar reasoning applies for establishments with 16 (not disabled) employees that are facing a negative demand shock. Compared to establisments with e.g. 15 or 17 employees, firing a worker lowers costs not only by the wage and non-wage costs of this employee but by DM 200 per month extra due to the fact that the penalty must no longer be paid. Therefore, the incentive to reduce employment in times of negative demand shocks is hypothesized to be higher in establishments with 16 employees than in slightly smaller or larger establishments ceteris paribus.

Information on the actual role played by the first threshold due to the disability law in small firm job dynamics in Germany is scarce. Beside anecdotal evidence telling stories of bosses of craft shops who did not hire the much needed sixteenth plumber or carpenter (evidently not a job easily done by a disabled person) and extended overtime instead, we have some results based on surveys of firms pointing rather vaguely to negative effects of the penalty rule for job creation (Diery, Schubert and Zink 1997; Friedrich and Hägele 1997). Empirical evidence based on econometric investigations is missing, and we are not aware of any econometric study on the effects of similar thresholds in other countries. In this note we intend to fill this gap. The rest of the paper is organised as follows: Section 2 introduces the data used in our study, section 3 discusses the method we applied in our empirical investigation and presents the results, and section 4 concludes.

\section{Data}

An econometric analysis of the effects of the threshold value of the German disability law on job dynamics must be based on a set of longitudinal data at the establishment level with detailed information on the number of employees covered by social insurance, and the data must contain information on positive and negative demand shocks facing the establishments. Longitudinal data, or panel data, are needed because we must be able to foll ow the units over time; furthermore, panel data allow to control for unobserved heterogeneity. Establishment level data are needed because 
the law is written in terms of the number of employees in a local production unit, or Betrieb, and not in terms of the number of employees in a legal unit (enterprise, or U nternehmen). Detailed information on the number of employees covered by social security is needed because the owner plus members of his family (who are not covered) and apprentices do not count for the threshold under consideration. Information on positive and negative demand shocks are needed for obvious reasons. Furthermore, the data set must cover a sufficient number of small establishments with numbers of employees that lie just below, exactly at, or just behind the threshold under consideration. To the best of our knowledge there is only one data set in Germany available that fulfils these rather demanding requirements, ${ }^{4}$ the IA B Establishment Panel of the Institute for Employment Research of the Federal Labor Services in Germany (or Institut für A rbeitsmarkt- und Berufsforschung, IA B).

This panel surveys some 4000 establishments from all sectors of the economy in West Germany once in a year since 1993 (and about the same number of establishments in East Germany since 1996). In 1998, the data set contains information for some 9,000 observations. It is based on a stratified random sample (using strata for 16 industries and 10 size classes) from the population of all local production units with at least one employee covered by social insurance. To correct for panel mortality, exits, and newly founded units, the samples are augmented regularly, leading to an unbalanced panel data set. Participation of establishments is voluntary, and the response rates (above 70 percent) are high compared to other non-official German firm panel studies. Data are collected in personal interviews with the owners or managers of the establishments by professional interviewers. The panel is created to serve the needs of the Federal Labor Services, so its focus is on employment related matters. ${ }^{5}$

One caveat should be mentioned: The IA B Establishment Panel has no information on the number of disabled employees in an establishment. To see why this could be a cause for concern

\footnotetext{
${ }^{4}$ Unfortunately, therefore, our investigation cannot be based on comparative evidence from more than one data set. Given that this is the first econometric study on the effects of the threshold under consideration, using other data sets to replicate or revise our findings is especially important, and we offer any help to do so.

${ }^{5}$ For more information on the IA B E stablishment Panel see Kölling (2000). N ote that the data are confidential but not exclusive. Those interested in using the data for scientific (non-commercial) research should contact the third author via e-mail: arnd. koellingdiab. de .
} 
imagine two establishments with 15 employees, one with (at least) one disabled employee (call it company A) and one with no disabled employees (call it company B). If both companies face an identical positive demand shock and hire one more (not disabled) employee, only company B will have to pay the penalty of DM 200 per month. According to our hypothesis, therefore, company B will have a lower probability to create a new job than company A. Without information about the number of disabled workers in an establishment both companies are classified as "exactly at the threshold", and this leads to an errors-in-variables problem in the context investigated here. However, given that we have no information that the probability of employing at least one disabled worker differs systematically between establishments just before, exactly at, and just behind the threshold under consideration, we would argue that this does not harm our conclusions. 


\section{Econometric investigation}

Our econometric investigation of the role played by German disability law's first threshold in small firm job dynamics is based on data from the IA B Establishment Panel described in section 2 above. We consider all West German establishments working for profit ${ }^{6}$ that participated in the survey in at least two consecutive years between 1993 and 1998. Using these data we test two hypotheses derived from theoretical considerations and stated in the introductory section 1 above:

Hypothesis 1: Establishments at the first threshold of the German disability law facing a positive demand shock have a ceteris paribus lower probability of hiring one more employee than establishments below or above this threshold?

H ypothesis 2: Establishments at the first threshold of the German disability law facing a negative demand shock have a ceteris paribus higher probability of firing one employee than establishments below or above this threshold.

As regards hypothesis 1 , an establishment is considered to lie at the threshold if it has 15 employees covered by social insurance (excluding apprentices) at June 30 of year $t$, because hiring one more (not disabled) worker would mean to cross the border from below. To compare like with like, establishments with 13 or 14 (16 or 17) employees are considered to lie just below (above) the threshold ${ }^{8}$ An establishment is considered to face a positive demand shock if the interviewed

\footnotetext{
${ }^{6}$ East German establishments were excluded because of the rather short time span since the survey started. Non-profit sectors like universities and public administration are excluded because labor demand in these parts of the economy cannot be expected to follow standard economic reasoning. The Stata jobs used for all calculations are available from the first author to facilitate replications and extensions.

${ }^{7}$ It should be noted that due to data limitations we cannot test what could be called the "second part" of this hypothesis, namely that establishments at the threshold will either in the short run extend the number of hours worked per employee and/ or substitute capital for labor in the long run instead. From the survey we have no information on the capital stock of the establishments, and information on overtime is not available in the detailed form needed here.

${ }^{8}$ As a caveat we have to admit that the data do not allow an exact sorting of establishments at the threshold and behind due to missing detailed information about part-time workers and the hours worked by parttimers. Without going into details of the law, what we would need to calculate exactly would be some kind of full-time equivalent number of employees. Given that this information is missing in the survey, an establishment with 15 "heads counted" might well have
} 
person states that an increase in theeconomic activity (or Geschäftsvolumen) of the establishment is expected between this year and the next.

As regards hypothesis 2, an establishment is considered to lie at the threshold if it has 16 employees covered by social insurance (excluding apprentices) at June 30 of year $t$, because firing one worker would mean to cross the border from above. Again to compare like with like, establishments with 17 or 18 (14 or 15) employees are considered to lie just above (below) the threshold. An establishment is considered to face a negative demand shock if the interviewed person states that a decrease in the economic activity (or Geschäftsvolumen ) of the establishment is expected between this year and the next.

The endogenous variable in the empirical model to test hypothesis 1 is a dummy variable with the value one if the establishment reports a higher number of employees covered by social insurance (excluding apprentices) for June 30 in year $t+1$ than for June 30 in year $t$, and the value zero otherwise. Similarly, the endogenous variable in the empirical model to test hypothesis 2 is a dummy variable with the value one if the establishment reports a lower number of employees covered by social insurance (excluding apprentices) for June 30 in year $t+1$ than for June 30 in year $\mathrm{t}$, and the value zero otherwise.

Both empirical models contain the following exogenous variables: A dummy variable indicating whether the establishment has been at the threshold or not in year $t$, a dummy variable showing whether the establishment was facing a positve (in case of hypothesis 1) or negative (in case of hyposthesis 2) demand shock in year t, an interaction term of the threshold dummy and the demand shock dummy, and a set of dummy variables for the various two-year periods covered to control for fixed time effects (economy-wide business conditions, etc.). The models were estimated with pooled data from 1993/ 94 to 1997/ 98 forming an unbalanced panel. The method of estimation was random effects probit in order to control for unobserved heterogeneity of establishments.

less "full-time equivalents", and, therefore, might be misclassified as being at the margin. A similar reasoning applies in establishments with 16 or more "heads" but less than 15 "full-time equivalents", that might be misclassified as above the margin while being at it or even below. Unfortunately, we cannot solve this errors-in-variables problem.

${ }^{9}$ All computations were done with Stata Release 7. Note that it was not possible to estimate the model by fixed effects logit, too, because using this estimator would mean to exclude all 
Descripitive statistics for data used to investigate hypothesis 1 and 2 are given in table 1 and table 3 , respectively, and econometric results are reported in table 2 and table 4.

[Table 1 near here]

We start with a look at table I. 23 percent of all establishments were at the threshold with 15 employees in year $t$, and from the data for the distribution of establishments across various sizes we have no evidence for congestion at the threshold. About one third of all firms increased employment between year $t$ and year $t+1$, while a little more than one in four establishments faced a positive demand shock. Six percent of all establishments were threshold firms with a positive shock.

[Table 2 near here]

According to hypothesis 1 we expect the estimated coefficient of the threshold dummy to be negative, indicating that establishments at the threshold have a lower probability to increase employment than establishments below or above this threshold, ceteris paribus. Results reported in table 2 support this. Furthermore, the estimated coefficient of the demand shock variable is positive as expected, indicating that establishments that reported to expect an increase in their volume of business in thad a higher probability to increase the number of employees between $t$ and $t+1$ - this coefficient, however, is not significantly different from zero at a conventional statistical level. If hypothesis 1 holds we expect the interaction term of the threshold dummy and the demand shock dummy to be negative, indicating that being a threshold establishment lowers the effect of a positive demand shock, but the results do not support this. ${ }^{10}$

establishments that had the same value of the endogenous variable in all periods (e.g. that did not grow ever), and evidently this makes no sense here.

${ }^{10}$ Because the cost of an additional worker might vary across industries and, therefore, the penalty for not hiring a disabled person might vary in its marginal effect, we also ran the regressions separately for establishments from manufacturing $(\mathrm{N}=188)$ and services $(\mathrm{N}=218)$. The estimated coefficients are all insignificant at the five percent level; the point estimates for the threshold dummy and the interaction term of threshold and shock, however, are much larger for services 
Some indication as to the size of the threshold effect can be achieved by a simple simulation exercise: Taking the results reported in table 2 at face value the estimated probability for an increase in employment between $t$ and $t+1$ for an establishment that is not at the threshold and not facing a positive demand shock in the first time period considered is 0.56 , while a threshold establishment without a positive shock has a much lower value of 0.41 . The difference is less clear for firms with a positive shock; the estimated probabilities are 0.66 and 0.63 for non-threshold and threshold establishments, respectively. From table 2, therefore, we have only weak empirical evidence in favor of hypothesis $1^{11}$

[Table 3 near here]

Next, consider hypothesis 2 . From table 3 we see that 21 percent of all establishments were at the threshold with 16 employees in year t, and from the data for the distribution of establishments across various sizes we have again no evidence for congestion at the threshold. 40 percent of all firms decreased employment between year $t$ and year $t+1$, while a little more than one in four establishments faced a negative demand shock. Six percent of all establishments were threshold firms with a negative shock. N ote that the last two numbers are more or less identical for the group of establishments used to test hypothesis 1.

[Table 4 near here]

Let us now turn to the econometric results results reported in table 4. According to hypothesis 2 we expect the estimated coefficient of the threshold dummy to be positive, indicating that establishments at the threshold have a higher probability to decrease employment than establishments below or above this threshold, ceteris paribus. Results in table 4 do not support this.

establishments than for manufacturing establishments. The tables with the results are available on request.

${ }^{11} \mathrm{~N}$ ote that the null hypothesis that the random effects are all zero cannot be rejected at any level of significance (the probvalue is 0.9958); therefore, the estimation results from the random effects probit model are numerically identical to the results from a simple pooled probit model. 
The estimated coefficient of the threshold dummy is positive as expected, but not statistically different from zero at a conventional level, and the same holds true for the estimated coefficient of the demand shock variable. If hypothesis 2 holds we expect the interaction term of the threshold dummy and the demand shock dummy to be positive, indicating that being a threshold establishment increases the effect of a negative demand shock, but again the results do not support this. $^{12}$

An indication as to the size of the threshold effect can be achieved by simulation, using the results reported in table 4: The estimated probability for a decrease in employment between $\mathrm{t}$ and $t+1$ for an establishment that is not at the threshold and not facing a negative demand shock in the first time period considered is 0.23 , whilea threshold establishment without a negative shock has a much higher value of 0.33 . This difference is smaller for firms with a negative shock; the estimated probabilities are 0.31 and 0.37 for non-threshold and threshold establishments, respectively. From table 4 , therefore, we have no compelling evidence in favor of hypothesis $2^{13}$

\section{Concluding remarks}

According to the results of our econometric investigation the first threshold of the German disability law does not seem to have the kind of strong negative influence on job dynamics in small firms that is often attributed to it in public debates. On the other hand we cannot reject the two hypotheses tested in a way that would allow us to state that the threshold does not matter at all.

Frankly, these somewhat inconclusive results can arise (at least, in part) due to problems with the data mentioned earlier, i.e. missing information on (changes in) overtime, capital stock, employment of disabled persons, parttime employees, and strength of demand shocks.

\footnotetext{
${ }^{12}$ A gain, the models were estimated separately for establishments from manufacturing ( $\left.N=191\right)$ and services ( $N=206$ ). Only the coefficient of the demand shock variable in the model using data from manufacturing is statistically different from zero at the five percent level of significance; all other coefficients are insignificant. The tables with the results are available on request.

${ }^{13}$ Again the null hypothesis that the random effects are all zero cannot be rejected at any level of significance (the probvalueis 0.9963); see footnote 8.
} 
Furthermore, even in the large samples of the IAB Establishment Panel there are only small numbers of establishments with 13 to 18 employees, and this might lead to imprecise estimates.

Another point might be that the amount of DM 200 an establishment has to pay (will save) as a penalty when crossing the threshold from below (above) is too small to act as an incentive. Economists are used to think at the margin - practitioners may not.

The new law effective from October 1, 2000 has increased the penalty up to DM 500 (if the share of disabled employees is below 2 percent) while at the same time rising the first threshold to 20 employees. This introduces somekind of natural experiment. Future research will show whether and how establisments do react to these changes. For the next four years or so, however, the evidence presented in this paper is all we have.

\section{References}

Deutscher Bundestag (2000), Antwort der Bundesregierung auf die Kleine Anfrage der Abgeordneten Johannes Singhammer et al.: Ausgleichsabgabe für Schwerbehinderte, Bundestagsdrucksache 14/ 3031 vom 10. 5. 2000.

Diery, Hartmuth, Hans-Joachim Schubert and Klaus J. Zink (1997), Die Eingliederung von Schwerbehinderten in das Arbeitsleben aus der Sicht von Unternehmen - Ergebnisse einer empirischen Untersuchung, Mitteilungen aus der Arbeitsmarkt- und Berufsforschung 30, 442454.

Frick, Bernd and Joachim Frick (1994), Labor Market Policy and the Convergence of Interests: The "Benefits" of the German Handicapped Act for Employers and Employees, in: Johannes Schwarze, Friedrich Buttler and Gert G. Wagner (Eds.), Labour Market Dynamics in Present Day Germany, Frankfurt/ N ew York, 217-239.

Friedrich, Werner and Helmut Hägele (1997), Ökonomische Konsequenzen von Schwellenwerten im Arbeits- und Sozialrecht sowie die Auswirkungen dieser Regelungen, Studien der ISG Sozialforschung und Gesellschaftspolitik Band 20, Köln. 
Henninges, Hasso von, Thomas Jung-Hammon und Hannelore Gruber (1998), A rbeitsmarktsituation von Schwerbehinderten, IAB-Werkstattbericht Nr. 13 vom 17. 11. 1998, Nürnberg.

Institut der deutschen Wirtschaft (1998), Arbeitsrecht: Gesetzliche Stolpersteine, iwd Informationsdienst des Instituts der deutschen Wirtschaft 24, No. 30, 23. Juli 1998, 6-7.

Kölling, Arnd (2000), The IAB-Establishment Panel, Schmollers Jahrbuch - Zeitschrift für Wirtschafts- und Sozial wissenschaften 120, 291-300.

Sadowski, Dieter und Bernd Frick (1992), Die Beschäftigung Schwerbehinderter:

Betriebswirtschaftliche Analysen und politische Empfehlungen, Idstein. 
Table 1: Descriptive Statistics for Data used to investigate Hypothesis 1

Distribution of establishments across various sizes

No. of employees in $t$ 13

14

15

16

17
Percentage of establishm.

20.75

22.17

23.11

20.52

13.44

Variables in the empirical model

\section{Mean}

Std. Dev.

Increase in employment

between $t$ and $t+1$

0.35

0.48

Threshold dummy

0.23

0.42

Positive demand shock dummy

0.28

0.45

Interaction term of

threshold and positive shock

0.06

0.25

Source: Own calculations with data from the IAB

Establishment Panel; selected industries

Pooled data for $1993 / 94$ to $1997 / 98$ 
Table 2: Results for Hypothesis 1

Endogenous variable: Increase in employment

between

$t$ and $t+1$ (Dummy; 1 = yes, $0=$ no)

Estimation method: Random effects probit

Threshold

Dummy: 1 = establishment with 15

employees in $t ; 0=$ otherwise

Demand shock

Dummy; 1 = increase in activity

expected between $t$ and $t+1$

Interaction term of threshold dummy and demand shock dummy

Time period dummies

included

Random establishment effects

Constant

0.16

$(1.10)$

Number of establishments

$$
406
$$

Pseudo- $\mathrm{R}^{2}$

0.09

Source: Own calculations with data from the IAB

Establishment Panel; selected industries

Establishments with 13 to 17 employees in $t_{0}$

Pooled data for $1993 / 94$ to $1997 / 98$

Values in brackets are absolute t-values;

* indicates statistical significance at the

5 percent level 
Table 3: Descriptive Statistics for Data used to investigate Hypothesis 2

Distribution of establishments across various sizes

$\begin{array}{rc}\text { No. of employees in } t & \text { Percentage of establishm. } \\ 14 & 22.54 \\ 15 & 23.50 \\ 16 & 20.86 \\ 17 & 13.67 \\ 18 & 19.42\end{array}$

Variables in the empirical model

Mean Std. Dev.

Decrease in employment

$\begin{array}{lll}\text { between } t \text { and } t+1 & 0.40 & 0.49\end{array}$

Threshold dummy

0.21

0.40

Negative demand shock dummy 0.26

0.44

Interaction term of

threshold and negative shock $0.06 \quad 0.23$

Source: Own calculations with data from the IAB Establishment Panel; selected industries

Pooled data for $1993 / 94$ to $1997 / 98$ 
Table 4: Results for Hypothesis 2

Endogenous variable: Decrease in employment between

$t$ and $t+1$ (Dummy; 1 = yes, $0=$ no)

Estimation method: Random effects probit

Threshold

0.29

Dummy: 1 = establishment with 16

employees in $t ; 0=$ otherwise

Demand shock

0.23

Dummy; 1 = decrease in activity

expected between $t$ and $t+1$

Interaction term of threshold dummy

and demand shock dummy

Time period dummies

included

Random establishment effects

included

Constant

$$
-0.74^{\star \star}
$$

Number of establishments

397

Pseudo-R ${ }^{2}$

0.06

Source: Own calculations with data from the IAB Establishment Panel; selected industries Establishments with 14 to 18 employees in $t_{0}$ Pooled data for $1993 / 94$ to $1997 / 98$

Values in brackets are absolute t-values;

** indicates statistical significance at the

1 percent level 


\section{IZA Discussion Papers}

\begin{tabular}{|c|c|c|c|c|}
\hline No. & Author(s) & Title & Area & Date \\
\hline 372 & $\begin{array}{l}\text { J. Konings } \\
\text { H. Lehmann }\end{array}$ & $\begin{array}{l}\text { Marshall and Labour Demand in Russia: Going } \\
\text { Back to Basics }\end{array}$ & 4 & 09/01 \\
\hline 373 & S. J. Trejo & $\begin{array}{l}\text { Does the Statutory Overtime Premium } \\
\text { Discourage Long Workweeks? }\end{array}$ & 1 & $10 / 01$ \\
\hline 374 & $\begin{array}{l}\text { G. J. van den Berg } \\
\text { B. van der Klaauw }\end{array}$ & $\begin{array}{l}\text { Counseling and Monitoring of Unemployed } \\
\text { Workers: Theory and Evidence from a } \\
\text { Controlled Social Experiment }\end{array}$ & 6 & $10 / 01$ \\
\hline 375 & $\begin{array}{l}\text { J. A. Dunlevy } \\
\text { W. K. Hutchinson }\end{array}$ & $\begin{array}{l}\text { The Pro-Trade Effect of Immigration on } \\
\text { American Exports During the Late Nineteenth } \\
\text { and Early Twentieth Centuries }\end{array}$ & 1 & $10 / 01$ \\
\hline 376 & G. Corneo & Work and Television & 5 & $10 / 01$ \\
\hline 377 & S. J. Trejo & $\begin{array}{l}\text { Intergenerational Progress of Mexican-Origin } \\
\text { Workers in the U.S. Labor Market }\end{array}$ & 1 & $10 / 01$ \\
\hline 378 & $\begin{array}{l}\text { D. Clark } \\
\text { R. Fahr }\end{array}$ & $\begin{array}{l}\text { The Promise of Workplace Training for Non- } \\
\text { College-Bound Youth: Theory and Evidence } \\
\text { from German Apprenticeship }\end{array}$ & 1 & $10 / 01$ \\
\hline 379 & $\begin{array}{l}\text { H. Antecol } \\
\text { D. A. Cobb-Clark }\end{array}$ & $\begin{array}{l}\text { The Sexual Harassment of Female Active-Duty } \\
\text { Personnel: Effects on Job Satisfaction and } \\
\text { Intentions to Remain in the Military }\end{array}$ & 5 & $10 / 01$ \\
\hline 380 & M. Sattinger & $\begin{array}{l}\text { A Kaldor Matching Model of Real Wage } \\
\text { Declines }\end{array}$ & 7 & $10 / 01$ \\
\hline 381 & $\begin{array}{l}\text { J. T. Addison } \\
\text { P. Teixeira }\end{array}$ & The Economics of Employment Protection & 3 & $10 / 01$ \\
\hline 382 & L. Goerke & Tax Evasion in a Unionised Economy & 3 & $11 / 01$ \\
\hline 383 & $\begin{array}{l}\text { D. Blau } \\
\text { E. Tekin }\end{array}$ & $\begin{array}{l}\text { The Determinants and Consequences of Child } \\
\text { Care Subsidies for Single Mothers }\end{array}$ & 3 & $11 / 01$ \\
\hline 384 & $\begin{array}{l}\text { D. Acemoglu } \\
\text { J.-S. Pischke }\end{array}$ & Minimum Wages and On-the-Job Training & 1 & $11 / 01$ \\
\hline 385 & $\begin{array}{l}\text { A. Ichino } \\
\text { R. T. Riphahn }\end{array}$ & $\begin{array}{l}\text { The Effect of Employment Protection on Worker } \\
\text { Effort: A Comparison of Absenteeism During } \\
\text { and After Probation }\end{array}$ & 1 & $11 / 01$ \\
\hline 386 & $\begin{array}{l}\text { J. Wagner } \\
\text { C. Schnabel } \\
\text { A. Kölling }\end{array}$ & $\begin{array}{l}\text { Threshold Values in German Labor Law and Job } \\
\text { Dynamics in Small Firms: The Case of the } \\
\text { Disability Law }\end{array}$ & 3 & $11 / 01$ \\
\hline
\end{tabular}

